Tabun XIII Volume 13 Nomor 2 Edisi 6 Desember 2019

ISSN 0216-079X E-ISSN 2685-3043

Balai Bahasa Kalimantan Barat

\title{
KAJIAN STILISTIKA NOVEL PADUSI KARYA KA'BATI
}

\section{A STYLISTICS STUDY PADUSI NOVEL BY KA'BATI}

\author{
Daratullaila Nasri \\ Balai Bahasa Provinsi Sumatra Barat \\ daratullaila.nasri@kemdikbud.go.id
}

\begin{abstract}
ABSTRAK
Penelitian ini bertujuan mengungkapkan kekhasan gaya bahasa pengarang dalam novel Padusi karya Ka'bati. Masalah penelitian adalah apa gaya bahasa yang digunakan oleh pengarang dalam mengungkapkan ide-ide dan pemikirannya tentang kehidupan TKI di luar negeri. Oleh karena itu, pendekatan yang digunakan adalah stilistika. Stilistika dalam hal ini hanya melihat aspek kebahasaan dan tidak menyentuh ranah isi. Aspek kebahasaan itu dipaparkan dengan konsep dikemukakan oleh Gorys Keraf. Metode yang digunakan dalam penelitian ini adalah metode kualitatif. Dari hasil penelitian itu dapat disimpulkan beberapa gaya bahasa yang digunakan oleh pengarang. Gaya bahasa tersebut berdasarkan struktur kalimat dan langsung tidaknya makna. Gaya bahasa berdasarkan struktur kalimat dominan ditemukan gaya bahasa klimaks. Gaya bahasa berdasarkan langsung tidaknya makna terbagi atas dua retoris dan kiasan. Pada retotis, gaya bahasa yang dominan ditemukan, yaitu gaya bahasa eufimisme, paradoks, tautologi. Pada kiasan, gaya bahasa yang dominan ditemukan gaya bahasa metafora, smile, dan ironi. Masing-masing gaya bahasa tersebut memiliki fungsi yang berbeda-beda. Fungsi-fungsi tersebut mengungkapkan potret TKI di di luar negeri.
\end{abstract}

Kata kunci: padusi, stilistika, gaya bahasa.

\begin{abstract}
This research has purpose to reveal the characteristic of author's figure of speech in Padusi novel by Ka'bati. The object of this research is to discover whether the figure of speech which used by the author shows his ideas and thought regarding the live of Indonesian labor in foreign country. Therefore, the approach used is stylistic. Stylistic, in this matter, merely sees the linguistic aspect and does not graze the content. The linguistic aspect is exposed using a concept set by Gorys Keraf. Method used in the research is qualitative. Out of this research can be concluded that there are several figure of speech used by the author. Those figures of speech are based on the structure of the sentences and either the sentences are direct or not. Figures of speech based on the structure of sentences are majority found as climax figure of speech. Based on the meaning directness, it divided into two, which is rhetorical and allegory. In rhetorical, the one most found is euphemism, paradox and tautology. In allegory, the ones found the most are metaphor, simile, and irony. Each figure of speech has its own different function. Those function exposed the portrait of Indonesian labor aboard.
\end{abstract}

Keywords: Padusi, stylistic, figure of speech 
Tahun XIII Volume 13 Nomor 2 Edisi 6 Desember 2019

ISSN 0216-079X E-ISSN 2685-3043

Balai Bahasa Kalimantan Barat

\section{PENDAHULUAN}

Persoalan Tenaga Kerja Indonesia di luar negeri bak benang kusut yang tidak kunjung selesai. Belum adanya upaya dari pemerintah dan instansi terkait secara sungguh-sungguh untuk menyelesaikan segala persoalan nasib para penyumbang devisa terbesar itu. Satu-persatu korban berjatuhan, tetapi mereka tidak tahu ke mana mesti mengadukan nasibnya. Ketidakadilan yang mereka deritakan di negeri orang terpaksa mereka tanggungkan sendiri-sendiri. Walau kadang ketika pulang mereka harus membawa beban jiwa dan raga yang tidak akan pernah mereka lupakan seumur hidupnya.

Ka'bati dalam novel perdananya yang berjudul Padusi menghadirkan kepada kita potret Tenaga Kerja Indonesia (selanjutnya di tulis TKI) yang ada di luar negeri, khususnya di Semenanjung Malaya. Novel mengisahkan nasib perempuan Minangkabau, Dinar dan Sahara yang terpaksa menjadi TKI demi meraih impian melanjutkan sekolah di perguruan tinggi. Kehidupan menjadi buruh kontrak di negeri orang yang mereka jalani diharapkan dapat membawa mereka pada impian-impiannya.

Namun, impian tidak sesuai dengan kenyataan. Di sana mereka diperlakukan tidak adil. Misalnya, Pemotongan gaji yang semena-mena, praktik peraturan yang memihak pada pribumi sehingga para pendatang dianaktirikan. Di tambah lagi, pelayanan kesehatan yang seadanya dan alat transportasi ke tempat kerja yang tidak memadai dan sebagainya.

Apa yang dialami Dinar dan Sarah dalam novel tersebut merupakan gambaran atau potret TKI yang bekerja sebagai buruh pabrik di luar negeri, khususnya Malaysia. Untuk memahami apa yang dimaksudkan pengarang dalam kisah tersebut kita harus memahami bahasanya. Sebagaimana dinyatakan Teeuw (1991: 12) bahwa kode pertama yang harus dikuasai seorang pembaca dalam memberi makna terhadap teks (karya sastra) adalah bahasa.

Dengan demikian, penelitian ini ingin melihat bagaimana kekhasan kebahasaan pengarang dalam menuangkan ide-ide dan pemikirannya tentang kehidupan TKI di luar negeri. Lebih khusus, tulisan ini membicarakan gaya bahasa yang digunakan pengarang dan dari gaya bahasa tersebut akan dilihat fungsinya.

Ada pun penelitian yang telah memanfaatkan novel Padusi sebagai objek kajian adalah berikut ini. 1) "Ketidakadilan Gender terhadap Perempuan dalam Novel Padusi Karya Ka'bati (Nasri, 2016:225--236). 2) Potret Buram TKI dari Perempuan Minangkabau dalam Novel Padusi Karya Ka'bati (Kajian Sosiologi Sastra) (Nasri, 2018:93--107). 3) "Perjuangan Perempuan dalam Novel Padusi Karya Ka'bati Analisis Kritik Sastra Feminis (Atlydia, 2015). 4) "Kepribadian Tokoh Utama dalam Novel Padusi Karya Ka'bati Tinjauan Psikologi Sastra" (Weni, 2016). 5) "Analisis Feminis Novel Padusi Karya Ka,bati”. (Tumanggor, Desi Melia. 2018).

Sementara itu, penelitian yang terkait dengan kajian stilistika diantaranya adalah "Pemanfaatan Aspek Stilistika dalam Antologi Puisi Melipat Jarak Karya Sapardi Djoko Damono sebagai Materi Pengayaan Sastra di SMA" (Mukhlis dan Mimi, 2018:54--60). Selanjutnya, penelitian yang dilakukan oleh Fransori (2017:1--12) dengan judul "Analisis Stilistika pada Puisi Kepada Peminta-Minta 
Karya Chairil Anwar". selain itu, Yasin juga melakukan kajian stilistika dengan judul "Kajian Stilistika dalam Teks Al-Mutawassimin sebagai Bahan Pembelajaran Mata kuliah Wajib Stilistika" ( 2016:195--206).

Kode bahasa meliputi juga gaya (style). Bagi Enkvist (dalam Junus, 1989: 21), gaya juga diartikan sebagai rangkaian ciri pribadi atau karakter kebahasaan yang khas dari seorang pengarang yang tidak dimiliki oleh pengarang yang lain. Menurut Hendricks (Junus, 1989: 21) gaya pribadi tersebut dilihat sebagai parole, konsep linguitistik Ferdinand de Saussure. Parole merupakan ciri kebahasaan pribadi pada masing-masing individu dalam mengaktualisasikan langue. Sehubungan dengan itu, saya ingin melihat bagaimana karakter kebahasaan Ka'bati dalam menggambarkan kehidupan TKI di luar negeri. Untuk membahas karakter kebahasaan tersebut digunakan pendekatan stilistika dalam tulisan ini.

Menurut Junus (1989), stilistik atau stilistika berhubungan style atau 'gaya'. Dalam konteks pengkajian sastra, gaya dihungkan dengan pemakaian atau penggunaan bahasa dalam karya sastra. Teeuw (1993: 13) memaknai stilistika sebagai ilmu gaya bahasa. Pada prinsipnya gaya bahasa yang dimaksudkan oleh Teeuw adalah pemakaian bahasa yang khas atau istimewa yang merupakan ciri khas seorang penulis, aliran sastra, pemakaian bahasa yang menyimpang dari bahasa sehari-hari atau dari bahasa yang dianggap normal, baku dan sebagainya.

Demikian juga halnya dengan Sudjiman (1993: 13) yang menyatakan bahwa pusat perhatian stilistika adalah style, cara yang digunakan seorang pembicara atau penulis untuk menyatakan maksudnya dengan menggunakan bahasa sebagai sarana. Style itu pun dimaknai Sudjiman sebagai gaya bahasa. Lebih lanjut Sudjiman menyatakan bahwa dalam konteks sastra, batasan stilistika, yaitu (1) mengkaji wacana sastra dengan orientasi linguistik, (2) mengkaji cara sastrawan memanipulasi-dengan arti memanfaatkan-unsur dan kaidah yang terdapat dalam bahasa dan efek apa yang ditimbulkan oleh penggunaannya. Menurut Keraf $(2005,113)$ style atau gaya bahasa dapat dibatasi sebagai cara mengungkapkan pikiran melalui bahasa secara khas yang memperlihatkan jiwa dan kepribadian penulis (pemakai bahasa).

Keraf (2005: 115-117) membagi jenis gaya bahasa atas dua bagian, yaitu segi nonbahasa dan segi bahasa. Gaya bahasa nonbahasa terdiri atas, yakni (1) berdasarkan pengarang, (2) berdasarkan masa, (3) berdasarkan medium, (4) berdasarkan subyek, (5) berdasarkan tempat, (6) berdasarkan hadirin, dan (7) berdasarkan tujuan. Gaya bahasa segi bahasa terbagi atas empat bagian, yaitu (1) gaya berdasarkan pilihan kata, (2) gaya bahasa berdasarkan nada yang terkandung dalam wacana, gaya bahasa berdasarkan struktur kalimat, dan (4) gaya bahasa berdasarkan langsung tidaknya makna.

Dengan konsepsi yang diuraikan di atas, penulis ingin mengungkapkan kekhasan kebahasaan pengarang dalam menuangkan ide-ide dan pemikirannya tentang kehidupan TKI di luar negeri. Dalam mengungkapkan kekhasan bahasa pengarang tersebut, saya melihatnya dari gaya bahasa yang digunakan. Dari gaya bahasa tersebut akan dilihat fungsinya. 


\section{METODE}

Penelitian ini menggunakan metode kualitatif. Secara sederhana, penelitian kualitatif diartikan sebagai penelitian yang tidak mengadakan perhitungan (Moleong, 1989: 2). Berdasarkan pemikiran Bodgan dan Taylor, Moleong (1989: 3) mendefinisikan metodologi kualitatif sebagai prosedur penelitian yang menghasilkan data deskriptif berupa kata-kata tertulis atau lisan.

Sumber data penelitian ini adalah novel Padusi karya Ka'bati (2010) cetakan pertama. Proses pengumpulan data dilakukan dengan studi pustaka melalui teknik simak dan catat (Mahsun, 2014).

\section{PEMBAHASAN}

Untuk melihat gaya bahasa yang digunakan pengarang dalam mengungkapkan kehidupan TKI di luar negeri, penulis mengacu pada gaya bahasa yang dikemukakan oleh Keraf tersebut. Gaya bahasa yang dapat dikemukakan di sini adalah (1) gaya bahasa berdasarkan struktur kalimat: klimaks dan antitesis, (2) gaya bahasa berdasarkan langsung tidaknya makna: (a) gaya bahasa retorik: anastrof, eufeumisme, pleonasme, tautologi, perifrasis, dan paradoks, (b) gaya bahasa kiasan: smile, metafora, epitet, hipalase, sarkasme, satire, antifrasis, dan ironi. Berikut ini dapat dilihat masing-masing penjelasan gaya bahasa tersebut.

\section{GAYA BAHASA BERDASARKAN STRUKTUR KALIMAT Klimaks}

Klimaks diturunkan dari kalimat yang bersifat periodik (Keraf,2005: 124). Lebih lanjut dijelaskan Keraf, bahwa klimaks, mengandung urutan-urutan pikiran yang setiap kali semakin meningkat kepentingannya dari gagasan-gagasan sebelumnya. Perhatikan contoh kutipan berikut ini.

(1) Sepanjang sejarah di negeriku yang beradat, belum pernah ada peristiwa seperti ini sebelumnya. Baru pada beberapa tahun belakangan kebijakan itu ada. Pemerintah mengerahkan tenaga kerja perempuan untuk bekerja sebagai buruh di luar negeri. Tidak hanya ke Semenanjung Malaya dan Singapura, tetapi juga ke Korea, Hongkong, Jepang, bahkan Arab Saudi (Ka'bati, 2010: 9-10).

(2) ... Di hostel sebelahnya, tinggal laki-laki Bangladesh gaya hidup serupa. Mereka tidak suka memakai alas kaki, dan senang memakai sarung. Kebanyakan sudah tua-tua, jadi tak sama dengan pekerja dari negaraku yang sengaja mengirim gadis-gadis, bahkan anak di bawah umur. Walau sebenarnya, peraturan ketenagakerjaan membatasi umur buruh migran antara tujuh belas sampai lima puluh tahun (Ka'bati, 2010: 94-95).

(3) Satu kali teman sekamarku, Yeni, berubah perilaku. Semenjak dia berteman dengan gadis Melayu yang tinggal di lantai tiga, dia menjadi sangat aneh. Dia memang tomboi dan perokok semakin kelelakian-lelakian. Dengan terang-terangan dia merayu gadis-gadis bekerja lainnya. deman lesbian mulai berjangkit. Tidak hanya di kamarku, tapi di hampir seluruh bagian perindu ini (Ka,bati, 2010: 115). 
(4) Menyusul beberapa gadis Aceh kabur. Pabrik geger. Penjagaan hostel semakin diperketat. Kami gerah diperlakukan seperti hewan piaraan. Tidak saja keringat yang diperas, kebebasan melihat dunia luar dikerangkeng. Bagi mereka memperoleh buruh kontrak sama artinya mendapatkan seluruh diri kita. Dengan membayar gaji untuk keringat yang kami keluarkan, mereka berpikir telah mebayar untuk seluruh kehidupan kami, para buruh. (Ka'bati, 2010: 148).

(5) Demonstrasi tak membawa perubahan berarti. Beberapa pemimpin buruh yang menyerukan pemberontakan dipulangkan tanpa membawa apa pun. Sementara, bagi mereka yang tinggal, memilih pasrah dan diamdiam bekerja lagi. Bekerja dan bekerja lebih rajin, bahkan tak mengenal waktu, tujuh hari dalam sepekan, malam atau siang. Ancaman pemulangan adalah hal yang dicemaskan setiap buruh. Sangat memalukan bagi perantau kalau sampai pulang tanpa hasil. Hujan batu harus ditahankan (Ka'bati, 2010: 151).

\section{Antitesis}

Antitesis adalah gaya bahasa yang mengandung gagasan yang bertentangan, dengan mempergunakan kata-kata atau kelompok kata yang berlawanan (Keraf: 2005: 126).

(6) ... Tahulah aku, bagaimana pendirian perempuan itu. Buruh dalam pandangannya tak lebih dari kelompok manusia yang diperalat oleh sistem kapitalis untuk keuntungan besar bagi si pemiliki modal, tapi belenggu kebebasan dan penderitaan bagi si buruh. Karena itulah kerja menjadi buruh adalah pekerjaan rendahan kehinaan memang dekat dengan kebodohan, dan di sanalah pemegang buruh berkubang (Ka'bati, 2010: 94).

(7) Belakangan, banyak pekerja yang melarikan diri karena tergiur bekerja dengan gaji yang lebih besar di tempat lain. Atau karena tidak tahan dengan tekanan di tempat kerja, lalu memutuskan kembali ke kampung secara ilegal. Karena kalau memutuskan kontrak kerja secara resmi, maka masing-masing kami harus mengeluarkan biaya tebusan mencapai lima ribu ringgit. Itu tak mungkin terkumpulkan selama bekerja (Ka'bati, 2010: 136).

Gaya bahasa berdasarkan struktur kalimat lebih dominan dalam bentuk klimaks. Gaya bahasa klimaks ini digunakan berfungsi untuk menggambarkan kepada pembaca atas apa yang dialami TKI. Setelah gambaran tetang kehidupan TKI tersebut dapat ditangkap oleh indera pembaca, diharapkan pembaca juga menangkap makna yang terkandung di dalam gaya bahasa tersebut. Untaian gagasan yang bertingkat terdapat dalam gaya bahasa tersebut, masing-masingnya memberikan makna yang berbeda terhadap pembaca.

Adapun antitesis yang terdapat dalam Padusi berfungsi untuk memperlihatkan posisi TKI di luar negeri yang serba susah. Sebagai buruh kontrak, mereka selalu dipihak yang dirugikan, sedangkan pemodal selalu diuntungkan. 


\section{GAYA BAHASA BERDASARKAN LANGSUNG TIDAKNYA MAKNA Gaya Bahasa Retoris \\ Anastrof}

Anastrof atau inversi adalah gaya bahasa retoris yang diperoleh dengan pembalikan susunan kata yang biasa dalam kalimat (Keraf, 2005: 130).

(8) Profesi itu tak membawa perubahan berarti. Beberapa orang yang dicurigai sebagai penghasut dipulangkan dengan alasan yang dibuat-dibuat. Beberapa hari setelah kerusuhan, kami semua diberitahukan bahwa pemerintah mewajibkan seluruh buruh untuk mengecek kesehatan. berbondong-bondonglah kami pergi ke satu klinik yang telah ditentukan pihak perusahaan. Sehari setelah cek up selesai, keluar lah surat yang menyatakan beberapa orang terkena AIDS, paru-paru bolong, bahkan ada yang hamil(Ka,bati, 2010: 111-114).

\section{Eufemisme}

Eufemisme adalah ungkapan-ungkapan yang tidak menyingung perasaan orang, atau ungkapan-ungkapan halus uantuk menggantikan acuan-acuan yang mungkin dirasakan menghina,menyinggung perasaan atau mensugesti sesuatu yang tidak menyenangkan (Keraf, 2005: 132).

(9) Tekanan pertama yang kurasa sebagai kuli kontrak adalah transportasi. Sebetulnya, perusahaan menyediakan bus angkutan bagi para pekerja,tetapi aku lebih senang menempuh jarak dua setengah kilo dari hostel ke pabrik dengan berjalan kaki. Kebiasaan yang dulu juga aku jalani ketika bekerja di toko. Sungguh tak tahan aku berebutan dan berdesakandengan ratusan buruh laki-laki dan perempuan lainnya. terutama orang-orang Bangla yang kasar dan bau keringat yang luar biasa bagi hidungku. Tidak hanya aroma tubuh, tetapi juga ludah merah yang menyembur-nyembur seenaknya dari mulut mereka saat bicara, sangat membuatku risih. Bangla-bangla tua itu memang sangat gemar mengunyah sirih.air sirih di mulut mereka terpercik ke mana-mana saat berteriak dan berebutan di bus (Ka'bati, 2010: 96-97).

(10) Proses itu tak membawa perubahan berarti. Beberapa orang yang dicurigai sebagai penghasut dipulangkan dengan alasan yang dibuatdibuat. Beberapa hari setelah kerusuhan, kami semua diberitahukan bahwa pemerintah mewajibkan seluruh buruh untuk mengecek kesehatan. berbondong-bondonglah kami pergi ke satu klinik yang telah ditentukan pihak perusahaan. Seharai setelah cek up selesai, keluar lah surat yang menyatakan beberapa orang terkena AIDS, paru-paru bolong, bahkan ada yang hamil(Ka,bati, 2010: 111-114).

(11) Mereka yang didakwa berpenyakit, adalah para pembangkang. Dewi harus pulang ke Sunda karena positif hamil, padahal dia gadis tomboi yang jarang sekali berdekatan dengan lelaki. Entah hamil oleh siapa, dia sendiri sepertinya begitu kaget sewaktu menerima peringatan itu. Vivi didakwa kena virus HIV dan harus pulang ke Sumatera. Begitulah nasib mereka yang dipaksa pulang. Sementara, bagi mereka yang tinggal, memilih untuk 


\section{Balai Bahasa Kalimantan Barat}

diam dan bekerja kembali dengan patuh.mereka tentu saja takut dipulangkan (Ka,bati, 2010: 111—114).

(12) Dia baru saja terlibat demonstrasi menggugat perbaikan upah. Karena kesal dengan ulah tersebut, pihak perusahan konon telah memasukkan namanya dalam daftar orang-orang yang akan dipulangkan (Ka'bati, 2010: 136).

(13) Beruntung mereka yang berwajah cantik dan bertubuh bagus. Golongan itu bisa menyusup di bawah ketatnya peraturan. Mereka menawarkan kelebihan fisiknya, dibeli dengan beberapa kepingan ringgit. Biasanya lebih dulu menikmati adalah para bos pabrik, baru kemudian menyebar ke tempat lain. Akhirnya, karena keasyikan bekerja sebagai pelayan seks, para buruh yang berubah status menjadi bohsia, mau bergelimang keringat melayani nafsu rendah para laki-laki Bangla dan Pakistan. Lelaki Bangladesh dan Pakistan kebanyakan lugu dan sangat senang dengan perempuan Indonesia. Mereka mau mengeluarkan banyak uang untuk mendapatkannya, apalagi mereka tahu bahwa perempuan itu bekas pelayan seks bos Cina mereka. Tentu saja setelah perempuan itu tidak laku lagi di kalangan bos Cina, atau terdepak dari diskotik-diskotik (Ka'bati, 2010: 158).

(14) Demonstrasi tak membawa perubahan berarti. Beberapa pemimpin buruh yang menyerukan pemberontakan dipulangkan tanpa membawa apa pun. Sementara, bagi mereka yang tinggal, memilih pasrah dan diam-diam bekerja lagi. Bekerja dan bekerja lebih rajin, bahkan takmengenal waktu, tujuh hari dalam sepekan, malam atau siang. Ancaman pemulangan adalah hal yang dicemaskan setiap buruh. Sangat memalukan bagi perantau kalau sampai pulang tanpa hasil. Hujan batu harus ditahankan(Ka'bati, 2010: 151).

\section{Pleonasme dan Tautologi}

Pleonasme dan Tautologi adalah acuan yang mempergunakan kata-kata yang lebih banyak daripada yang diperlukan untuk menyatakan satu pikin dan gagasan. Meskipun kedua istilah itu sama, ada juga yang membedakan. Apabila kata yang berlebihan dihilangkan, artinya tetap utuh. Hal itu disebut pleonase. Sebaliknya, kalau kata yang berlebihan itu sebenarnya mengandung perulangan dari sebuah kata yang lain disebut tautologi (Keraf, 2005: 133).

\section{Contoh pleonase:}

(15) Setiap pagi, bus-bus pejemput itu akan datang ke perindu dengan suara klakson yang memekakkan telinga, memanggilpara buruh untuk bergegas. Seperti dikejar-kejar vampir, karena memang harus begitu kalau tak ingin gajinya dipotong atas keterlambatan, walau hanya satu menit. Tanpa mengenal kelamin atau bangsa, setiap orang menggapai, menaiki bus-bus. Tak jarang terjadi baku hantam untuk mendapatkan kurasi tempat duduk. Yang sering kali berkelahi seperti ituadalah pekerja Bangla dengan Melayu (Ka'bati, 2010: 97). 
Contoh tautologi:

(16)... Tapi kulihat orang Melayu maupun India Tamil hanya bagian buruh dari perusahaan-perusahaan, sama seperti orang Indonesia, Bangladesh, dan Pakistan yang berdatangan merangkaki kawasan tersebut. Mereka seperti iring-iringan semut menghampiri manisan yang tumpah di beceknya tanah bernama Semenanjung Malaya (Ka'bati, 2010: 95).

(17) Tekanan pertama yang kurasa sebagai kuli kontrak adalah transportasi. Sebetulnya, perusahaan menyediakan bus angkutan bagi para pekerja,tetapi aku lebih senang menempuh jarak dua setengah kilo dari hostel ke pabrik dengan berjalan kaki. Kebiasaan yang dulu juga aku jalani ketika bekerja di toko. Sungguh tak tahan aku berebutan dan berdesakan dengan ratusan buruh laki-laki dan perempuan lainnya. terutama orang-orang Bangla yang kasar dan bau keringat yang luar biasa bagi hidungku. Tidak hanya aroma tubuh, tetapi juga ludah merah yang menyembur-nyembur seenaknya dari mulut mereka saat bicara, sangat membuatku risih. Bangla-bangla tua itu memang sangat gemar mengunyah sirih. Air sirih di mulut mereka terpercik ke mana-mana saat berteriak dan berebutan di bus (Ka'bati, 2010: 96-97).

(18) Aku tiba-tiba berada dalam posisi penyulut kemarahan. Beberapa orang dari mereka adalah pembangkang-pembangkang pemberani, yang hampir setiap malam sebelum kerusuhan terjadi, berkumpul di tangga kamarku. Mereka selalu menyertakanku sebagai sumber ide. Aku sama sekali tidak menyadari bahwa pikirankulah yang turut menimbulkan pemberontakan itu (Ka'bati, 2010: 113).

\section{Perisfrasis}

Perisfrasis hampir mirip dengan pleonasme, yaitu mempergunakan kata lebih banyak dari yang diperlukan. Perbedaannya terletak dalam hal bahwa katakata yang berlebihan itu dapat diganti dengan satu kata saja (Keraf, 2005: 134).

(19) Di sinilah aku merasakan bahwa tak ada perbedaan antara buruh migran seperti kami dengan siapa pun. Aku boleh menikamti fasilitas apa saja di tempat ini, sama seperti yang dibolehkan pada setiap anggota lainnya. Aku dibebaskan meminjam dan membaca buku sepuaspuasnyanya. Aku juga boleh meminjam beberapa kepingan video untuk diputar di lantai tiga(Ka'bati, 2010: 106-107).

(20) ... Tetapi apa dayaku, gaji yang kuterima tak pernah cukup. Setiap bulan, ada saja potongan yang dikenakan pada kami, entah potongan visa, dana pembinaan buruh migran yang dipungut pemerintahan,untuk agen yang menyalurkan kami sampai potongan untuk air,listrik, gas, kebersihan, dan segalanya. Pernah kami menerima gaji hanya beberapa ringgit saja(Ka'bati, 2010: 113).

\section{Paradoks}

Paradoks adalah gaya bahasa yang mengandung pertentangan yang nyata dengan fakta yang ada (Keraf, 2005: 136). 


\section{Balai Bahasa Kalimantan Barat}

(21) ... Di hostel sebelahnya, tinggal laki-laki Bangladesh gaya hidup serupa. Mereka tidak suka memakai alas kaki, dan senang memakai sarung. Kebanyakan sudah tua-tua, jadi tak sama dengan pekerja dari negaraku yang sengaja mengirim gadis-gadis, bahkan anak di bawah umur. Walau sebenarnya, peraturan ketenagakerjaan membatasi umur buruh migran antara tujuh belas sampai lima puluh tahun (Ka'bati, 2010: 94-95).

(22) Suatu kali Sahara bertanya padaku tentang gaji yang tak lagi sesuai dengan kebutuhan dan janji-janji yang digombalkan Mr.Tee. Aku berusaha tenang, menyembunyikan gejolak emosiku (Ka'bati, 2010: 113).

(23) Mereka yang didakwa berpenyakit, adalah para pembangkang. Dewi harus pulang ke Sunda karena positif hamil, padahal dia gadis tomboi yang jarang sekali berdekatan dengan lelaki. Entah hamil oleh siapa, dia sendiri sepertinya begitu kaget sewaktu menerima peringatan itu. Vivi didakwa kena virus HIV dan harus pulang ke Sumatera. Begitulah nasib mereka yang dipaksa pulang. Sementara, bagi mereka yang tinggal, memilih untuk diam dan bekerja kembali dengan patuh.mereka tentu saja takut dipulangkan (Ka,bati, 2010: 111-114).

(24) Keadaan keuangan juga tidak makin membaik dari waktu ke waktu. Menabung sedikit ringgit yang tersisa untuk dikirim pada orang tua di kampung, konsekuensinya menahan selera makan sebisanya. Makan dengan ikan kering dan beras berbubuk, atau mencari tambahan pendapatan lain dengan berbagai cara. Pilihannya terlalu sulit (Ka'bati, 2010: 148).

\section{Asidenton}

Gaya bahasa yang berupa acuan, yang bersifat padat dan mampat di mana beberapa kata, frasa, atau klausa yang sederajat tidak dihubungkan dengan kata sambung. Bentuk-bentuk itu biasanya dipisahkan saja dengan koma (Keraf, 2005: 131).

(25) Malaya. Di negeri itu, kulihat ribuan, bahkan mungkin ratusan ribu buruh migran digelandang pulang kampung mereka. Lelaki buntung, perempuan bunting, bayi-bayi. Semua, mereka, diusir seperti binatang. Dihalau dan dicambuki . Lalu, luka yang kupunya seperti terinfeksi. Ngilu di jantung hati. Serasa aku melihat ada dia di sana. Di tengah mereka berlari dengan wajah cemas pada haluan yang tak jelas. Dia, dia, dan aku (Ka'bati, 2010: 8).

(26) Sementara, bagi mereka yang tinggal, memilih pasrah dan diamdiam bekerja lagi. Bekerja dan bekerja lebih rajin, bahkan takmengenal waktu, tujuh hari dalam sepekan, malam atau siang. Ancaman pemulangan adalah hal yang dicemaskan setiap buruh. Sangat memalukan bagi perantau kalau sampai pulang tanpa hasil. Hujan batu harus ditahankan (Ka'bati, 2010: 151). 
Gaya bahasa berdasarkan langsung tidaknya makna dalam Padusi dominan ditemukan eufimisme, disusul paradoks, tautologi, perifrasis, asidenton, dan anastrof. Eufimisme yang cenderung digunakan adalah "dipulangkan". Kata "dipulangkan" adalah kata yang sangat menakutkan bagi TKI. Kata ini merupakan penghalusan dari kata 'pengusiran'. Tidak satu pun TKI yang mau dipulangkan. Oleh karena itu, eufimisme di sini berfungsi untuk menakut-nakuti, ancaman, dan sekaligus menuntut kepatuhan dari si buruh.

Gaya Paradoks berfungsi menggambarkan sesuatu yang dialami seseorang. Ketika seseorang mengalami sesuatu muncul hal-hal yang berlawanan, baik dalam diri sendiri maupun di luar dirinya (orang di sekitarnya dan lingkungan), sebagai individu ia harus memilih salah satu dari yang berlawanan itu. Perifrasis berfungsi memberikan penekanan agar makna yang kehendaki sampai pada pembaca. Dalam Padusi tersebut terlihat bahwa pengarang menekankan kepada pembaca begitu banyak penderitaan TKI, terutama dapat dilihat dari gaji yang mereka terima. Banyak sekali potong-potongan yang harus diambilkan dari gaji sehingga TKI hanya menerima beberapa ringgit saja.

Asidenton yang terdapat dalam Padusi sangat padat dan mengandung makna yang sangat dalam. "Laki-laki buntung, perempuan bunting, bayi-bayi. Semua diusir seperti binatang. Di halau dan dicambuki." Kata-kata itu jelas menggabarkan penderitaan yang dialami TKI. Dia antara mereka ada yang buntung kakinya, perempuan hamil, dan bayi-bayi. Semua diperlakukan secara tidak manusiawi. Demikian juga ketika mereka mendapat ancaman untuk dipulangkan, mereka terpaksa mimilih pasrah. "Bekerja dan bekerja lebih rajin" adalah jalan terbaik bagi mereka agar tidak dipulangkan.

Anastrof di sini jelas menekan pada kata yang terdapat diawal kalimat, kata "berbondong-bondong" bukan kata "kami". Dengan pemilihan kata "berbondongbondong" tersebut tergambar antusiasme TKI untuk memeriksakan kesehatannya. Namun, di balik itu semua adalah siasat untuk mengusir mereka yang memberontak terhadap perusahaan.

\section{GAYA BAHASA KIASAN}

\section{Smile}

Smile adalah perbandingan yang bersifat eksplisit. yang dimaksudkan dengan perbandingan yang bersifat eksplisit ialah bahwa ia langsung menyatakan sesuatu sama dengan hal yang lain (Keraf, 2005: 138).

(27) Malaya. Di negeri itu, kulihat ribuan, bahkan mungkin ratusan ribu buruh migran digelandang pulang kampung mereka. Lelaki buntung, perempuan bunting, bayi-bayi. Semua, mereka, diusir seperti binatang. Dihalau dan dicambuki. Lalu, luka yang kupunya seperti terinfeksi. Ngilu di jantung hati. Serasa aku melihat ada dia di sana. Di tengah mereka berlari dengan wajah cemas pada haluan yang tak jelas. Dia, dia, dan aku (Ka'bati, 2010: 8).

(28) Begitu pintu pesawat terbuka, puluhan gadis muda berseragam merah-putih saling dorong melalui tangga pesawat.wajah mereka harap-harap cemas, seperti serombongan pengantin perempuan yang akan dinikahkan dengan lelaki yang hanya mereka kenal lewat 


\section{Balai Bahasa Kalimantan Barat}

obrolan tukang sulo. Aku di antara mereka juga dengan perasaan yang sama (Ka'bati, 2010: 8-9).

(29) ... Tapi kulihat orang Melayu maupun India Tamil hanya bagian buruh dari perusahaan-perusahaan, sama seperti orangIndonesia, Bangladesh, dan Pakistan yang berdatangan merangkaki kawasan tersebut. Mereka seperti iring-iringan semut menghampiri manisan yang tumpah di beceknya tanah bernama Semenanjung Malaya (Ka'bati, 2010: 95).

(30) Setiap pagi, bus-bus pejemput itu akan datang ke perindu dengan suara klakson yang memekakkan telinga, memanggil para buruh untuk bergegas. Seperti dikejar-kejar vampir, karena memang harus begitu kalau tak ingin gajinya dipotong atas keterlambatan, walau hanya satu menit. Tanpa mengenal kelamin atau bangsa, setiap orang menggapai, menaiki bus-bus. Tak jarang terjadi baku hantam untuk mendapatkan kurasi tempat duduk. Yang sering kali berkelahi seperti ituadalah pekerja Bangla dengan Melayu (Ka'bati, 2010: 97).

(31) Ada sekitar lima bus yang disediakan, tapi angkutan sebanyak itu memang tak cukup untuk memuat ribuan pekerja. Jadilah mereka berdesak-desakan,seperti ikan sarden yang dikalengkan (Ka'btai, 2010: 97).

(32) Seperti ikan menemukan air, setiap akhir pekan aku membenamkan diri di dalamnya (Ka'bati, 2010: 106-107).

(33) Persoalan pendapat, suatu ketika menimbulkan kegaduhan. Pekerja mogok. Ada beberapa kawan yang gajinya dipotong seenaknya. Ada juga yang pendapatannya minus di akhir bulan. Kata pihak personalia, karena mereka malas bekerja. Kondisi buruk itu memancing solidaritas antarburuh. Seperti banteng terluka, para perempuan yang terkurung mengamuk melempar kaleng-kaleng, kayu, dan apa saja yang bisa mereka lemparkan keluar pagar.

(34) Menyusul beberapa gadis Aceh kabur. Pabrik geger. Penjagaan hostel semakin diperketat. Kami gerah diperlakukanseperti hewan piaraan. Tidak saja keringat yang diperas, kebebasan melihat dunia luar dikerangkeng. Bagi mereka memperoleh buruh kontrak sama artinya mendapatkan seluruh diri kita. Dengan membayar gaji untuk keringat yang kami keluarkan, mereka berpikir telah mebayar untuk seluruh kehidupan kami, para buruh (Ka'bati, 2010: 148).

\section{Metafora}

Metafora adalah analogi yang membandingkan dua hal secara langsung, tetapi dalam bentuk yang singkat (Keraf, 2005: 139).

(35) Jamariku tak bisa berhenti menari di atas kertas-kertas. Kumuntahkan segala kenangan tentang pahlawan yang kalah. Sementara di telinga,terus terngiang ratapan mereka yang terdampar di perbatasan sana (Ka'bati, 2010: 19). 
(36)... Tahulah aku, bagaimana pendirian perempuan itu. Buruh dalam pandangannya tak lebih dari kelompok manusia yang diperalat oleh sistem kapitalis untuk keuntungan besar bagi si pemiliki modal, tapi belenggu kebebasan dan penderitaan bagi si buruh.Karena itulah kerja menjadi buruh adalah pekerjaan rendahan kehinaan memang dekat dengan kebodohan, dan di sanalah pemegang buruh berkubang (Ka'bati, 2005: 94).

(37)... Tapi kulihat orang Melayu maupun India Tamil hanya bagian buruh dari perusahaan-perusahaan, sama seperti orang Indonesia, Bangladesh, dan Pakistan yang berdatangan merangkaki kawasan tersebut. Mereka seperti iring-iringan semut menghampiri manisan yang tumpah di beceknya tanahbernama Semenanjung Malaya (Ka’bati, 2010: 95).

(38) Setiap pagi, bus-bus pejemput itu akan datang ke perindu dengan suara klakson yang memekakkan telinga, memanggil para buruh untuk bergegas. Seperti dikejarkejar vampir, karena memang harus begitu kalau tak ingin gajinya dipotong atas keterlambatan, walau hanya satu menit. Tanpa mengenal kelamin atau bangsa, setiap orang menggapai, menaiki bus-bus. Tak jarang terjadi baku hantam untuk mendapatkan kurasi tempat duduk. Yang sering kali berkelahi seperti ituadalah pekerja Bangla dengan Melayu (Ka'bati, 2010: 97).

(39) Seperti ikan menemukan air, setiap akhir pekan aku membenamkan diri di dalamnya(Ka'bati, 2010:107).

(40) Aku tiba-tiba berada dalam posisi penyulut kemarahan. Beberapa orang dari mereka adalah pembangkang-pembangkang pemberani, yang hampir setiap malam sebelum kerusuhan terjadi, berkumpul di tangga kamarku. Mereka selalu menyertakanku sebagai sumber ide. Aku sama sekali tidak menyadari bahwa pikirankulah yang turut menimbulkan pemberontakan itu (Ka'bati, 2010: 113).

(41) Orang-orang Indon di sini saja banyak yang kosong. Maksudnya tentu tanpa dokumen yang resmi (Ka'bati, 2010: 129).

(42) Beruntung mereka yang berwajah cantik dan bertubuh bagus. Golongan itu bisa menyusup di bawah ketatnya peraturan. Mereka menawarkan kelebihan fisiknya, dibeli dengan beberapa kepingan ringgit. Biasanya lebih dulu menikmati adalah para bos pabrik, baru kemudian menyebar ke tempat lain. Akhirnya, karena keasyikan bekerja sebagai pelayan seks (gb eufeumisme), para buruh yang berubah status menjadi bohsia, mau bergelimang keringat melayani nafsu rendah para laki-laki Bangla dan Pakistan. Lelaki Bangladesh dan Pakistan kebanyakan lugu dan sangat senang dengan perempuan Indonesia. Mereka mau mengeluarkan banyak uang untuk mendapatkannya, apalagi mereka tahu bahwa perempuan itu bekas pelayan seks bos Cina mereka. Tentu saja setelah perempuan itu tidak laku lagi di kalangan bos Cina, atau terdepak dari diskotik-diskotik (Ka'bati, 2010: 158).

(43) Di mana pun status buruh kontrak dilarang terikat dengan perkawinan yang sah di tempatnya bekerja, tetapi soal mencicipi perempuan lain secara tidak sah, jelas tidak ada larangan. Para bohsia mendapatkan uang lebih banyak dengan cara itu. Karena uang dan banyak berkirim ke kampung adalah soal kebangaan (Ka'bati, 2010: 149). 
Tuab Talino

Tabun XIII Volume 13 Nomor 2 Edisi 6 Desember 2019

ISSN 0216-079X E-ISSN 2685-3043

Balai Bahasa Kalimantan Barat

\section{Epitet}

Epitet adalah acuan yang menyatakan suatu sifat atau ciri yang khusus dari seorang atau sesuatu hal (Keraf, 2005: 141).

(44) Untuk menambah belanja agar bisa menabung dan berkirim uang ke kampung, para buruh kontrak menjalankan profesi lain sebagai bohsia. Mulanya aku sama sekali tidak tahu, apa kerja mereka. Pemuas nafsu seks bagi laki-laki, alis pelacur. Sehingga lekatlah "bohsia Indon"menjadi panggilan atau umpatan bagi buruhbutuh perempuan dari Indonesia (Ka'bati, 2010: 115).

(45) Orang-orang Indon di sini saja banyak yang kosong. Maksudnya tentu tanpa dokumen yang resmi (Ka'bati, 2010: 129).

\section{Hipalase}

Hipalase adalah gaya bahasa dengan mempergunakan kata tertentu untuk menerangkan sebuah kata, yang seharusnya dikenakan pada sebuah kata yang lain (Keraf, 2005: 142).

(46) Kisah kucatat saat menjadi kuli kontrak, hidup di bawah tekanan pemodal, dan sorotan mata penuh hinadari warga pribumi. Perjuangan untuk terus mempertahankan harga dirimembuat kami memutuskan untuk memilih jalan lain. dia melanjutkan pelariannya ke tempat lain, sementara aku memutuskan untuk pulang (Ka'bati, 2010: 19).

\section{Sarkasme}

Sarkasme adalah suatu acuan yang mengandung kepahitan dan celaan yang getir (Keraf, 2005: 143).

(47) Perusahaan tidak mengizinkan buruh kontrak menikah, itu persoalan pertama, kecuali kami memutuskan kontrak kerja dan harus mengeluarkan sekian banyak biaya sebagai tebusan. Setelah itu, tentu saja mereka tidak menjamin kami bisa tetap tinggal di negara ini, kecuali mau dianggap sebagai pendatang haram. (Ka'bati, 2010: 138).

\section{Satire}

Satire adalah ungkapan yang menertawakan atau menolak sesuatu (Keraf, 2005, 144).

(48) Benar kata Oki. Penyakit apa saja yang diderita pekerja, selalu diobati Panadol. Bagi klinik, Panadol adalah penangkal semua penyakit (Ka'bati, 2010: 157).

\section{Antifrasis}

Antifrasis adalah semacam ironi yang berwujud penggunaan sebuah kata dengan makna kebalikannya, yang bisa saja dianggap sebagai ironi sendiri, atau kata-kata yang dipakai untuk menangkal kejahatan roh jahat, dan sebagainya. Antifrasis akan diketahui dengan jelas bila pembaca atau pendengar mengetahui 
atau dihadapkan pada kenyataan bahwa yang dikatakan itu adalah sebaliknya (Keraf, 2005: 145).

(49) Jamariku tak bisa berhenti menari di atas kertas-kertas. Kumuntahkan segala kenangan tentang pahlawan yang kalah. Sementara di telinga,terus terngiang ratapan mereka yang terdampar di perbatasan sana (Ka'bati, 2010: 19).

Catatan: pahlawan dalam konteks ini adalah pahlawan devisa pahlawan = menang dipertentangkan dengan kata kalah.

\section{Ironi}

Ironi adalah suatu acuan yang ingin mengatakan sesuatu dengan makna atau maksud berlainan dari pada yang terkandung dalam rangkaian kata-katanya (Keraf, 2005: 143).

(50) Suatu kali Sahara bertanya padaku tentang gaji yang tak lagi sesuai dengan kebutuhan dan janji-janji yang digombalkan Mr.Tee. Aku berusaha tenang, menyembunyikan gejolak emosiku. (Ka'bati, 2010: 113).

(51) Keadaan keuangan juga tidak makin membaik dari waktu ke waktu. Menabung sedikit ringgit yang tersisa untuk dikirim pada orang tua di kampung, konsekuensinya menahan slera makan sebisanya. Makan dengan ikan kering dan beras berbubuk, atau mencari tambahan pendapatan lain dengan berbagai cara. Pilihannya terlalu sulit (Ka'bati, 2010: 148).

(52) Demonstrasi tak membawa perubahan berarti. Beberapa pemimpin buruh yang menyerukan pemberontakan dipulangkan tanpa membawa apa pun. Sementara, bagi mereka yang tinggal, memilih pasrah dan diam-diam bekerja lagi. Bekerja dan bekerja lebih rajin, bahkan takmengenal waktu, tujuh hari dalam sepekan, malam atau siang. Ancaman pemulangan adalah hal yang dicemaskan setiap buruh. Sangat memalukan bagi perantau kalau sampai pulang tanpa hasil. Hujan batu harus ditahankan (Ka'bati, 2010: 151).

Gaya bahasa kiasan yang dominan dalam Padusi adalah Metafora, selanjutnya smile, ironi, epitet, sarkasme,hipalase, satire, dan antifrasis.

Metafora dalam Padusi tersebut tidak selalu hadir dalam hal yang berlawanan. Namun, satu kata atau lebih acuannya tidak sesuai dengan referensialnya. Misalnya, "buruh berkubang". Kata "berkubang" biasanya dilekatkan pada aktivitas binatang, seperti kerbau. Namun, dalam Padusi dilekatkan pada manusia. Gaya metafora dalam Padusi tersebut berfungsi untuk menyembunyikan sesuatu, tetapi sekaligus diungkapkan dengan cara yang lain.

Gaya smile berfungsi untuk menggambarkan peristiwa. Misalnya kalimat, "Semua, mereka, diusir seperti binatang. Dihalau dan dicambuki." "Wajah mereka harap-harap cemas, seperti serombongan pengantin perempuan yang akan dinikahkan dengan lelaki yang hanya mereka kenal lewat obrolan tukang sulo." "Mereka seperti iringan-iringan semut menghampiri manisan." "Jadilah mereka berdesak-desakan, seperti ikan sarden di kalengkan”. Semua kalimat tesebut 
menggiring imajinasi kita untuk menggambarkan sebuah peristiwa yang sedang dialami TKI.

Gaya ironi berfungsi untuk menggambarkan nasib buruk TKI. Gaya bahasa epitet, "bohsia Indon" dan "orang-orang Indon" merupakan julukan yang diberikan kepada orang Indonesia. "Bohsia Indon" di samping bermakna pelacur (berasal dari Indonesia), ungkapan itu juga menjadi panggilang atau umpatan bagi buruh-buruh perempun Indonesia. Sama halnya dengan "orang-orang Indon", yang mengacu kepada orang Indonesia, baik perempuan maupun laki-laki. Panggilan atau julukan itu menurut saya berfungsi untuk mematahkan mental orang-orang Indonesia yang bekerja sebagai buruh di sana.

Gaya bahasa sarkasme, hipalase, satire, dan antifrasis sedikit sekali ditemukan dalam Padusi. Masing-masing hanya satu contoh. Gaya sarkasme, seperti "pendatang haram" berfungsi mematahkan mental seseorang. Dengan menyebutkan 'pendatang haram' berarti orang tersebut tidak memiliki hak apa pun di daerah yang dia tempati. Gaya bahasa hipalase, "sorotan mata penuh hina dari warga pribumi" menggambarkan tidak bersahabatnya kaum pribumi terhadap para buruh. Gaya bahasa ini berfungsi untuk menggambarkan situasi atau suasana. Gaya bahasa satire berfungsi untuk mengungkapkan sesuatu dengan sejujur-jujurnya, tetapi diungkapkannya dengan cara yang lucu.

Gaya bahasa antifrasis ini berfungsi untuk menghadirkan kenyataan yang sebenarnya. Namun, dalam penyampaiannya, pengarang masih menyandingkan dengan kata yang memiliki sifat berlawanan, seperti "pahlawan yang kalah". Yang namanya "pahlawan" selalu dikonotasikan dengan menang. Akan tetapi, dalam hal ini yang ingin disampaikan oleh pengarang bahwa buruh telah kalah memperjuangkan nasibnya.

\section{PENUTUP}

Berdasarkan analisis di atas dapat disimpulkan bahwa potret TKI di luar negeri diungkapkan dengan gaya bahasa yang khas oleh pengarang. Gaya bahasa yang ditemukan adalah berdasarkan struktur kalimat dan langsung tidaknya makna. Gaya bahasa berdasarkan struktur kalimat dominan ditemukan gaya bahasa klimaks. Gaya bahasa berdasarkan langsung tidaknya makna terbagi atas dua retoris dan kiasan. Pada retotis, gaya bahasa yang dominan ditemukan, yaitu gaya bahasa eufimisme, paradoks, tautologi. Pada kiasan, gaya bahasa yang dominan ditemukan gaya bahasa metafora, smile, dan ironi. Masing-masing gaya bahasa tersebut memiliki fungsi yang berbeda-beda. Fungsi-fungsi tersebut mengungkapkan potret TKI di di luar negeri.

\section{DAFTAR PUSTAKA}

Aminuddin. (1995). Stilistika: Pengantar Memahami Bahasa dalam Karya Sastra. Semarang: IKIP Semarang Press.

Atlydia, Atripa. (2015). "Perjuangan Perempuan dalam Novel Padusi Karya Ka'bati Analisis Kritik Sastra Feminis. Padang: Sastra Daerah, Fakultas Ilmu Budaya, Universitas Andalas. 
Tabun XIII Volume 13 Nomor 2 Edisi 6 Desember 2019

ISSN 0216-079X E-ISSN 2685-3043

Balai Bahasa Kalimantan Barat

Fransori, Arinah. (2017). "Analisis Stilistika pada Puisi Kepada Peminta-Minta Karya Chairil Anwar". Dieksis, 9(1), (1--2).

Junus, Umar. (1989). Stilistika Satu Pengantar. Kuala Lumpur: Dewan Bahasa dan Pustaka Kementerian Pendidikam Malaysia.

Ka'bati. (2010). Padusi. Padang: Guci Publisher.

Keraf, Gorys. 2005. Diksi dan Gaya Bahasa. Jakarta: Gramedia Pustaka Utama.

Moleong, Lexi J. 1989. Metodologi Penelitian Kualitatif, Bandung: CV Remadja Karya.

Mukhlis, Abdul dan Mimi Mulyani. 2018. "Pemanfaatan Aspek Stilistika dalam Antologi Puisi Melipat Jarak Karya Sapardi Djoko Damono sebagai Materi Pengayaan Sastra di SMA”. Jurnal Penelitian Humaniora, 19(1), (54--60).

Nasri, Daratullaila. (2016). "Ketidakadilan Gender terhadap Perempuan dalam Novel Padusi Karya Ka'bati. Madah Jurnal Ilmiah Bahasa dan Sastra, 7(2), (225--236).

. (2018). "Potret Buram TKI dari Perempuan Minangkabau dalam Novel Padusi Karya Ka,bati (Kajian Sosiologi Sastra)". Jurnal Batra (Bahasa dan Sastra), 4(1), (93--107).

Sudjiman, Panuti. (1993). Bunga Rampai Stilistika. Jakarta: Pustaka Utama Grafiti.

Teeuw. A. (1991). Membaca dan Menilai Sastra. Jakarta: Gramedia Pustaka Utama.

. (1984). Sastra dan Ilmu Sastra: Pengantar Teori Ilmu Sastra. Jakarta: Pustaka Jaya.

Tumanggor, Desi Melia. (2018). Analisis Feminis Novel Padusi Karya Ka,bati. Medan: Sastra Indonesia, Fakultas Bahasa dan Seni, Universitas Negeri Medan.

Weni, Gusnita. (2016). "Kepribadian Tokoh Utama dalam Novel Padusi Karya Ka'bati Tinjauan Psikologi Sastra". Padang: Sastra Indonesia, Fakultas Ilmu Budaya, Universitas Andalas.

Yasin, Dhimas Muhammad. (2016). "Kajian Stilistika dalam Teks AlMutawassimin sebagai Bahan Pembelajaran Mata kuliah Wajib Stilistika”. Lingua, 13(2), (195--206). 